\title{
Diversification and corporate social performance in manufacturing companies
}

\author{
Dina Patrisia ${ }^{1,2}$ (D) Shabbir Dastgir ${ }^{1}$
}

Received: 16 December 2015/Revised: 2 June 2016/Accepted: 3 June 2016/

Published online: 1 July 2016

(C) The Author(s) 2016. This article is published with open access at Springerlink.com

\begin{abstract}
The effects of diversification on financial performance are well-established, less so the way in which diversification influences company behaviour towards stakeholder demand and social concern. This paper investigates the relationship between business diversification and corporate social performance (CSP) in an industrial setting, in Indonesia. CSP is measured with an index constructed from content and disclosure analysis of annual company reports in line with global reporting initiative standards. A sample of 107 listed manufacturing companies from the Indonesian Stock Exchange is used to estimate a lagged multiple regression model to show that industry-level diversification does not have an effect on CSP. However, distinguishing between related and unrelated diversification produces a different outcome whereby, related diversification is negatively and statistically significantly correlated with CSP. Unrelated diversification, on the other hand, shows a positive and statistically significant relationship. It means the relationship between unrelated diversification and CSP is more positive than the relationship between related diversification and CSP. The findings offer a unique insight into industrial diversification and CSP in Indonesia's expanding manufacturing sector.
\end{abstract}

Keywords Diversification - Related diversification - Unrelated diversification · CSP · Manufacturing · Indonesia

\footnotetext{
$\bowtie$ Dina Patrisia

Dina.Patrisia@hud.ac.uk

Shabbir Dastgir

s.dastgir@hud.ac.uk

1 Department of Strategy, Marketing and Economic, University of Huddersfield, Huddersfield, UK

2 Department of Management, State University of Padang, Padang, Indonesia
} 
JEL Classification L25 Company Performance: Size, Diversification, and Scope · M14 Corporate culture, Diversity, and Social Responsibility

\section{Introduction}

Diversification is an important strategy for a company that wants to enter the growth stage of a business life-cycle, or to create a competitive advantage, or to survive in the competition (Kang 2013; Montgomery 1994; Purkayastha et al. 2012; Rumelt 1974). Accordingly, diversification strategy has some benefits, such as creating synergy, market power (Montgomery 1994; Purkayastha et al. 2012), risk reduction (Martin and Sayrak 2003; Purkayastha et al. 2012), and internal capital market efficiency (Erdorf et al. 2013; Martin and Sayrak 2003; Purkayastha et al. 2012). On the other side, diversification also has several costs that emerge due to the asymmetry information (Berger and Ofek 1995; Chen and Yu 2012; Martin and Sayrak 2003), coordination(Chen and Yu 2012) and agency problems (Ataullah et al. 2014; Martin and Sayrak 2003; Su and Tsang 2015) which lead to internal coordination cost (Su and Tsang 2015). Hence, the benefit and cost of the diversification may have an impact on company performance (Chen and Yu 2012; George and Kabir 2012; Montgomery 1994; Palich et al. 2000; Purkayastha et al. 2012). For example, when a company has created synergy through diversification, it will lead to higher efficiency and it might effect a better performance of the company. However, diversification strategy of a company may also have a negative impact on performance. For instance, when a company has diversified its business and the company does not handle it properly, it may lead to a higher internal coordination cost which may cause lower performance. Accordingly, the impact of diversification on performance is still debatable and needs to be explored in future research.

Many prior studies have investigated the effect of diversification on a company's performance. However, these studies still focus on company financial performance (Kang 2013; Markides and Williamson 1994). Financial performance actually has some limitations, such as often failing to present long-term performance and survival of the company (Harrison and Wicks 2013; Kaplan and Norton 1996) and it only focuses on stockholders perspective assumptions; maximizing shareholder wealth (Barney 2011). Hence, another alternative in measuring company performance, which relies on multiple stakeholders and a useful predictor of long-term performance and viability is corporate social performance (CSP) (Kacperczyk 2009; Kang 2013). Therefore, nowadays, CSP has become an important component of overall company performance (Brammer et al. 2006). Although CSP is a potential indicator of a company's performance, however, research on the relationship between corporate diversification and CSP is neglected (Kang 2013). In addition, most of the prior studies have been conducted in the developed countries (Brammer et al. 2006; Kang 2013; Simerly 1997). Whilst, study on this topic is still missing in the developing countries, such as Indonesia. Hence, this study aims to examine the relationship between corporate diversification and CSP in Indonesia. In addition, in 
order to investigate this topic, this study is outlined as follows: introduction, theory and hypotheses, methods, analysis and conclusion and discussion.

\section{Theory and hypotheses}

Company performance is the result of activities in a particular period. For instance, Sahut et al. (2013) define the company performance as a perceptible result of company strategy adoption. Moreover, one of the company performance measurements is CSP. Some previous authors note that CSP measurement relies on multiple stakeholders' views (Brammer et al. 2006; Clarkson 1995; Kacperczyk 2009; Kang 2013; Zhang 2012). In addition, Clarkson (1995) argues that some of the corporate responsibilities to stakeholders also relate to social concern from society's perspective. Furthermore, Brammer et al. (2006) state CSP has become a principal component of business organization performance, since a company undertaking intense pressure from stakeholders, such as customers, employees, and socially responsible investors, need to show their commitment and contribution to society in social and environmental issues. Hence, we may argue that CSP is a performance measurement which reflects the company's response to stakeholder demands and social issues. Furthermore, some prior studies argue that CSP will be influenced by some factors, such as corporate diversification (Brammer et al. 2006; Kang 2013) and industrial visibility (Chiu and Sharfman 2011).

According to $\mathrm{Su}$ and Tsang (2015), diversification refers to a company, which operates in more than one industry or product market. Moreover, Park and Jang (2012) argue that diversification implies a company moving into a number of markets (sectors, industries, or segments), in which it was not previously engaged. Hence, a diversified company may have several different businesses or operate in multi businesses in terms of industry (product diversification), market or resources. According to several prior studies, industry or product diversification might be classified into three forms, including related diversification, unrelated diversification and total diversification (Chang and Wang 2007; Chen and Yu 2012; Hashai 2015; Oh et al. 2015; Palepu 1985; Su and Tsang 2015; Zahavi and Lavie 2013). Related diversification refers to diversification strategy which is associated with expanding business in a similar product or in the same product line (backward or forward integration) (Chen and Yu 2012). On the other hand, according to Castañer and Kavadis (2013) unrelated diversification refers to a diversification strategy that extend the company's operation into a different business which has a different input-output configuration or has limited common resources. Hence, we may argue that a company which adopts related diversification strategy, has related products and services, or participates in the same industry. On the other hand, a company which adopts unrelated diversification has different products and services or participates in a different industry or market. In addition, total diversification is a summary of both related diversification and unrelated diversification ( $\mathrm{Oh}$ et al. 2015; Palepu 1985; Su and Tsang 2015). Accordingly, there are three ways to measure product diversification, including related diversification (Larry 2010; 
Palepu 1985), unrelated diversification (Kim and Rasheed 2014; Palepu 1985) and total diversification (Amit and Livnat 1988b; Oh et al. 2015; Raghunathan 1995).

Furthermore, Kang (2013) asserts that there are several reasons why diversification has a relationship with CSP. First, the relationship between corporate diversification and CSP from a stakeholder perspective relies on the range of stakeholder demands and social issues faced by the company. Kang (2013) argues that the quantity and diversity of stakeholders that are pertinent to a company should be closely related to the operation range of the company. Hence, it means that increasing the company's range of business operations will increase the quantity and diversity of stakeholders and further could affect the range of stakeholder demands and social issues. Second, corporate diversification increases manager's risk aversion. According to Kang (2013), diversification strategy pushes the manager to choose safe strategic decisions which accommodates stakeholder demands and involve risk management. Third, diversification strategy may reduce managerial employment risk. Risk reduction in managerial employment on a diversified company occurs in two ways, including reducing company bankruptcy risk and management entrenchment (Alesón and Escuer 2002). Thus, it may reduce the variance of future cash flow (Martin and Sayrak 2003; Kang 2013; Shleifer and Vinishny 1989). Finally, a diversified company can share the cost and benefit of the CSP-related investments across their subsidiaries (McWilliams and Siegel 2001). Consequently, a diversified company has stronger economic encouragement to invest in social issues. Hence, from the discussion above, we may argue that corporate diversification has a relationship with CSP.

Several prior studies have investigated the relationship between related diversification and company performance (Gary 2005; Miller 2006; Park and Jang 2013; Su and Tsang 2015). For example, Su and Tsang (2015) reveal that product diversification relates to financial performance. Moreover, Miller (2006) notes that related diversification with capital intensity has a negative and significant relationship with company performance. Although both of the studies from $\mathrm{Su}$ and Tsang and Miller did not employ CSP as the organizational performance measurement, it may argue that related diversification has an impact on CSP. Furthermore, Kang (2013) asserts that related diversification is an antecedent of corporate social performance. Kang also asserts that related diversification relates to CSP but not significant in a negative direction. Slightly different, Gary (2005) and Chen and $\mathrm{Yu}$ (2012) reveal that a higher related diversification strategy may lead to a lower company performance. However, both of them have employed financial performance as company performance indicator instead of CSP. They argue that the diversification-performance relationship depends on the complexity of interaction among variables. Hence, synthesize potential synergy effect might need more investment in common resources and it will affect the company's performance. Nevertheless, most of the previous authors have argued that related diversification impacts upon organizational performance (Markides and Williamson 1994; Palich et al. 2000; Park and Jang 2012). Hence, we may argue that related diversification is an antecedent of CSP.

Furthermore, prior studies have argued that unrelated diversification has a link with organizational performance (Chatterjee and Wernerfelt 1991; Kang 2013; Kim 
1989; Palepu 1985; Park 2002; Park and Jang 2013; Su and Tsang 2015). For example, Kim et al. (1989) found that unrelated diversification strategy might be positively associated with organizational performance when companies are well diversified globally. Accordingly, most of the prior studies argue that diversification strategy, such as related and unrelated diversification is an antecedent of organizational performance (Kang 2013; Su and Tsang 2015).

Moreover, Purkayastha (2013) notes that unrelated diversification has a negative and significant relationship with ROA as one of the indicators of organizational performance. On the other hand, Su and Tsang (2015) accentuate that product diversification (related and unrelated) has a relationship with financial performance with secondary stakeholders as the moderating variable. Hence, from the discussion above, it may argue that unrelated diversification relates to organizational performance. Accordingly, because one of the organizational performance dimensions is the CSP, the researcher assumes that unrelated diversification strategy is positively related to CSP. However, to the best of the researcher's knowledge, prior studies on the link between diversification and CSP is neglected (Brammer et al. 2006; Kang 2013; Simerly 1997). For example, Brammer et al. (2006) have examined the link between diversification and CSP, but they only addressed geographical/international diversification as the variable. In addition, Simerly (1997) has only investigated the link between total diversification and CSP. Hence, as far as the researcher is aware, only Kang (2013) has examined the relationship between unrelated diversification strategy and CSP. In accordance with the above discussion, it may be argued that unrelated diversification is an antecedent of CSP.

Furthermore, different industries have different levels of significance to different social issues (Brammer and Millington 2008). Therefore, a company which adopts the unrelated diversification strategy operates its businesses in several different industries that are widely different in stakeholder demands and social issues. Conversely, a related diversified company, which conducts its businesses within an industry, has much more coherent stakeholder demands and social issues. In consequence, an unrelated diversified company deals with more diverging stakeholder demands and social issues, whilst, a related diversified company remains focused on a relatively narrow range of social concerns (Kang 2013). Moreover, Jackson and Apostolakou (2010) argue that industries represent an important boundary of institutional fields. They argue that institutional environment pressures on CSP might be different in a different industry, depending on the industry visibility. In addition, Chiu and Sharfman (2011) assert that industry visibility might relate to environmental level, financial and production risk, or the number of customers, the total employment, the amount of revenue, or taxes on an industry. Therefore, an industry which faces stronger institutional pressure might have a higher level of commitment to social responsible behaviour toward stakeholders (i.e. government, consumers and NGO's). Accordingly, a related diversified company, which operates in a less visible industry, has a lower pressure to implement corporate social responsibility (CSR) behaviours compared to an unrelated diversified company which has higher institutional environmental pressure.

Moreover, unrelated diversification strategy has a stronger effect on managerial risk aversion than the related diversification (Hoskisson and Hitt 1988; Kang 2013). 
In addition, the correlation of earnings in unrelated diversification is lower than the related diversification (Amit and Livnat 1988a; Purkayastha et al. 2012). Therefore, unrelated diversification will decrease managerial employment risk more effectively than the related diversification, and promote a stronger managerial response to social issues (Kacperczyk 2009; Kang 2013). Furthermore, Investment in social issues, which relate to CSP, helps companies create market intangible assets, such as reputation, brand and customer loyalty (Kang 2013; Luo and Bhattacharya 2009; McWilliams and Siegel 2001; Park et al. 2015; Wood 2010). The market intangible asset is particularly more relevant to an unrelated diversified company, who needs a more easily transferable brand across diverse products than a related diversified company (Kang 2013; Park et al. 1991). Considering these reasons, we may argue that the relationship between related diversification and CSP will be negative and the relationship between unrelated diversification and CSP will be positive. Regarding the above discussion, we propose three hypotheses.

H1: There is a positive significant relationship between total diversification and CSP.

$\mathrm{H} 2$ : There is a negative and significant relationship between related diversification and CSP.

H3: There is a positive and significant relationship between unrelated diversification and CSP.

\section{Methods}

This part describes the sample, data sources, variables and measurement.

\subsection{Sample and data source}

This study uses a purposive sampling of 139 listed manufacturing companies from the Indonesia Stock Exchange (IDX). Furthermore, because CSP is a long-term oriented indicator, the one-year lag regression model was applied in this study to anticipate the effect of corporate diversification toward CSP which was not occurring immediately or in the same period. Therefore, to fit with this model, there are two criteria for the sample. Firstly, a company must be listed in the IDX from 2012 to 2013, secondly, it must have published the annual report with a complete set of data for this research. From 139 Manufacture Companies which were listed in IDX in 2013, only 125 companies were fulfilling the criteria. Moreover, after the univariate outlier test with standard score 4 (Hair et al. 2010), and omitting companies without a score of 4 , the final samples consist of 107 companies. This study employs the annual report of the company in 2013 as the data source of CSP and CSP industry. While for other variables, including total corporate diversification, related diversification, unrelated diversification, public ownership, institutional ownership, government ownership, company size, company profitability, financial leverage, and intangible asset, this study uses companies' annual report in 2012, 
Indonesia capital Market directory (ICMD) 2013 and the Osiris database as the data sources.

\subsection{Variables and measurements}

This study employs three types of variable, including dependent, independent and control variable. The dependent variable in this study is CSP. CSP is company performance, which reflects company's response to stakeholder demands and social issues (Kang 2013). Most previous studies have employed several indicators in measuring CSP. For example, ethical rating, a multi-dimensional index calculated by a special agency, or ethical rating indicators in CSP measurement such as KLD (Aguilera-Caracuel et al. 2015; Kang 2013; Strike et al. 2006; EIRIS Brammer et al. 2006; Dam and Scholtens 2013). This measurement calculates several indicators which concern different stakeholder groups in different countries. Hence, a different agency has different indicators. However, ethical rating has some limitations. For example, KLD is only focus on the listed companies in the US stock exchange (Dam and Scholtens 2012; Peng and Yang 2014). Hence, KLD is not widely available in companies from developing country setting. Moreover, each agency interprets the concept of social performance subjectively, and this leads to different evaluation processes (Soana 2011). Therefore, content analysis based on CSP's indicators that are globally accepted, such as global reporting initiative (GRI), in a developing country setting is still needed. GRI has been considered as the most relevant organization in CSR disclosure (Gamerschlag et al. 2011). GRI offers specific performance indicators of CSR from economic, environmental and social categories that reflect actual CSR achievement (Bouten et al. 2011), that reflects the CSP. These indicators are drafted by various experts based on stakeholder consultation (Bouten et al. 2011), and accepted internationally (Bouten et al. 2011; Farneti and Guthrie 2009; Gamerschlag et al. 2011).

In measuring CSP, this study uses the disclosure index, which derives from content analysis of the extent of CSP in the company's annual report in 2013. The indicators of CSP in this study are different with the previous studies, such as Kang (2013) who used KLD index for CSP indicators. The indicators of CSP are adapted from social performance indicators of the GRI. Moreover, because this study is conducted in the transition period between GRI version 3 (G3) and GRI version 4 (G4), we adapt some indicators which are relevant for both GRI versions and it may become another new insight of this study. There are 80 indicators employed in this study from economic, environmental, and social performance indicators which consist of human right, labour practices and decent work, product responsibility and society. For example, coverage of the organization's defined benefit plans obligations in economic indicators, initiatives to provide energy-efficient or renewable energy, and reductions in energy requirements as a result of these initiatives in environmental indicators, operations with significant potential or actual negative impacts on local communities and practices related to customer satisfaction in social indicators. Furthermore, by using an unweighted disclosure index, every indicator is scored as 1 if disclosed and 0 otherwise. Therefore, the maximum possible score for the 
disclosure index in this study is 80 (80 indicators $\times 1=80$ ). In addition, total disclosure scores of each company are divided by the maximum possible score to present the disclosure index in percentages.

The second variable in this research is the independent variable. The independent variable consists of 3 variables, I.e. total corporate diversification, related diversification, and unrelated diversification. All of these variables are measured by using the entropy measure (E) as espoused by Jacquemin and Berry (Doaei et al. 2012; Jacquemin and Berry 1979; Palepu 1985; Purkayastha 2013). The advantages of using the entropy measure are objectivity, reliability and ability to capture the level and type of diversification concurrently (Martin and Sayrak 2003; Sambharya 2000). The entropy measure needs an established product classification system code to identify the product or industry diversification. This study employs the new version of the International Standard Industry Classification of All Economic Activities (ISIC) Revision 4 from United Nations (2008). ISIC is a coherent and consistent classification based on an international agreement on concepts, definitions, principles, and classification rules (Nation 2008). This classification is adopted internationally and used by the majority countries around the world to develop their national classification, including Indonesia. Moreover, ISIC Rev.4 has been used to develop the Indonesia standard Industry classification of All Economic Activities (Klasifikasi Baku Lapangan Usaha Indonesia/KBLI) (BPS 2009).

Finally, to control other variables which are predicted to have an impact on CSP based on extensive theoretical and empirical literature, this research applies public ownership (percentage of public ownership), Institutional ownership (percentage of institutional ownership), Governance ownership (Dummy governance ownership), board size (number of board of commissioner in Indonesia context), company size (Logarithm of Total Assets), financial leverage (Debt asset ratio; Total debt to total Assets), company profitability (Return on Asset; percentage of earnings before interest and taxes to total assets), Intangible assets (Market to book ratio; Market price to book value) and industry CSP (mean of CSP score by industry in 2 digit of ISIC) (Brammer et al. 2006; Dam and Scholtens 2012; Huang and Watson 2015; Kang 2013; Khan et al. 2013; Kilic et al. 2015; Lahouel et al. 2014; Li et al. 2015; McGuire et al. 2012; Nation 2008; Neubaum and Zahra 2006; Ntim and Soobaroyen 2013; Peng and Yang 2014; Walls et al. 2012). Thus, to summarise, Table 1 shows the operation of variables and measurement. Hence, in the next stage, we will discuss analysis of the data.

\subsection{Analysis}

In line with the research aim which wants to examine the relationship between corporate diversification and CSP, this study uses multiple regression analysis with one year lag model as the data analysis tool. The regression equations are as follows: 
Table 1 Operationalization of variable

\begin{tabular}{|c|c|c|c|}
\hline Variables & Definitions & Measurements & Sources \\
\hline \multicolumn{4}{|l|}{ Dependent variable } \\
\hline CSP & $\begin{array}{l}\text { CSP is company } \\
\text { performance, which } \\
\text { reflects company's } \\
\text { response toward } \\
\text { stakeholder demands } \\
\text { and social issues }\end{array}$ & $\begin{array}{l}\text { Unweighted disclosure } \\
\text { index derived from } \\
\text { content analysis by } \\
\text { using social } \\
\text { performance } \\
\text { indicators of GRI }\end{array}$ & $\begin{array}{l}\text { Bouten et al. (2011); } \\
\text { Gamerschlag et al. } \\
\text { (2011); Joseph and } \\
\text { Taplin (2011) }\end{array}$ \\
\hline \multicolumn{4}{|l|}{ Independent variables } \\
\hline $\begin{array}{l}\text { Total } \\
\text { diversification } \\
\text { (TD) }\end{array}$ & $\begin{array}{l}\text { Corporate strategy to } \\
\text { operate in different } \\
\text { business or industry } \\
\text { based on four digit } \\
\text { ISIC }\end{array}$ & $\begin{array}{l}\text { Entropy measure based } \\
\text { on four digit ISIC } \\
D T=\sum_{i=1}^{n} P_{i} x \ln \frac{1}{p_{i}} \\
\text { DT: Total } \\
\text { diversification } \\
\mathrm{P}_{\mathrm{i}}: \text { The share of the } \\
\text { segment } i \text { of group } \\
j \text { in the total sales of } \\
\text { the group }\end{array}$ & $\begin{array}{l}\text { Doaei et al. (2012); } \\
\text { Jacquemin and Berry } \\
\text { (1979); Kang (2013); } \\
\text { Kranenburg et al. } \\
\text { (2004); Lien and Li } \\
\text { (2013); Palepu (1985) }\end{array}$ \\
\hline $\begin{array}{l}\text { Related } \\
\text { diversification (DR) }\end{array}$ & $\begin{array}{l}\text { Corporate strategy to } \\
\text { operate in different } \\
\text { business based on four } \\
\text { digits ISIC but in the } \\
\text { same two digits ISIC }\end{array}$ & $\begin{array}{l}\text { Entropy measure based } \\
\text { on four digit ISIC but } \\
\text { in the same two digits } \\
\text { ISIC } \\
D R_{j}=\sum_{i \in j} P_{i}^{j} \ln \frac{1}{P_{i}^{j}} \\
D R=\sum_{j=1}^{m} D R_{j} x p_{j} \\
\mathrm{DR}_{\mathrm{j}} \text { : The related } \\
\text { diversification in } \\
\text { several segments } \\
\text { within an industry } \\
\text { groups } \\
P_{i}^{j} \text { : The share of the } \\
\text { segment } i \text { of group } \\
j \text { in the total sales of } \\
\text { the group } \\
D R: \text { The weighted } \\
\text { average of total } \\
\text { related diversification } \\
\text { within the entire } \\
\text { group share } \\
p_{j} \text { : The share of } j \text { th } \\
\text { group sales in the } \\
\text { total sales of the } \\
\text { company }\end{array}$ & $\begin{array}{l}\text { Chen and Yu (2012); } \\
\text { Jacquemin and Berry } \\
\text { (1979); Kang (2013); } \\
\text { Kranenburg et al. } \\
\text { (2004); Palepu (1985); } \\
\text { Park and Jang (2013) }\end{array}$ \\
\hline $\begin{array}{l}\text { Unrelated } \\
\text { diversification (DU) }\end{array}$ & $\begin{array}{l}\text { Corporate strategy to } \\
\text { operate in different } \\
\text { business or industry } \\
\text { based on two digits } \\
\text { ISIC }\end{array}$ & $\begin{array}{l}\text { Entropy measure based } \\
\text { on two digit ISIC } \\
D U=\sum_{i=1}^{m} P_{i} x \ln \frac{1}{p_{i}} \\
\text { DU: unrelated } \\
\text { diversification in all } \\
\text { entire group shares }\end{array}$ & $\begin{array}{l}\text { Chen and Yu (2012); } \\
\text { Jacquemin and Berry } \\
\text { (1979); Kang (2013); } \\
\text { Kranenburg et al. } \\
\text { (2004); Palepu (1985); } \\
\text { Park and Jang (2013) }\end{array}$ \\
\hline
\end{tabular}




$$
\operatorname{CSP}_{i 2013}=\beta_{1} \text { total diversification }_{i 2012}+\sum_{i=1}^{n} \beta_{i} \text { Control }_{i 2012}+\varepsilon_{i}
$$

$$
\begin{aligned}
\text { CSP }_{i 2013}= & \beta_{1} \text { related diversification } \\
i 2012 & +\beta_{2} \text { unrelated diversification }_{i 2012} \\
& +\sum_{i=1}^{n} \beta_{i} \text { Control }_{i 2012}+\varepsilon_{i} .
\end{aligned}
$$

Before using the regression analysis, we have conducted tests for the classical assumptions of the linear regression model, including multicollinearity, heteroscedasticity and wrong functional.

\section{Result}

Based on the data analysis, the result of the study will be divided into two parts, including descriptive statistics and regression analysis.

\subsection{Descriptive statistics}

Table 2 contains summary descriptive statistics for 107 sample companies. In general, the sample companies have quite varied value in every variable as shown in the maximum, minimum, mean and standard deviation value. Some variables give unique information on company sample, such as CSP and diversification. CSP, the dependent variable, has a minimum score $3.78 \%$ and the maximum score is $48.75 \%$. It means that the company with the maximum score disclose $3.75 \%$, or 3 of 80 indicators. Hence, on average the companies disclose $19.277 \%$ or 15.42 indicators. Therefore, it can be concluded that CSP in the sample companies is low. Furthermore, for

Table 2 Descriptive statistic and correlation

\begin{tabular}{lccrr}
\hline Variables & Minimum & Maximum & Mean & \multicolumn{1}{c}{ SD } \\
\hline 1. CSP & 3.75 & 48.75 & 19.276 & 7.778 \\
2. Total diversification & 0.00 & 1.26 & 0.349 & 0.369 \\
3. Related diversification & 0.00 & 0.74 & 0.101 & 0.205 \\
4. Unrelated diversification & 0.00 & 1.11 & 0.248 & 0.309 \\
5. Public ownership & 1.00 & 66.93 & 23.550 & 16.083 \\
6. Institutional ownership & 0.00 & 99.00 & 68.321 & 23.482 \\
7. Government ownership & 0.00 & 1.00 & 0.065 & 0.248 \\
8. Board size & 2.00 & 9.00 & 4.009 & 1.611 \\
9. Company size & 9.27 & 17.98 & 14.005 & 1.501 \\
10. Financial leverage & 0.04 & 1.32 & 0.476 & 0.219 \\
11. Company profitability & -25.38 & 45.55 & 7.015 & 10.952 \\
12. Intangible asset & -3.16 & 10.48 & 1.842 & 2.178 \\
13. Industry CSP & 12.50 & 40.00 & 20.727 & 5.366 \\
\hline
\end{tabular}


diversification variables, which capture diversification strategy in sample companies, the minimum entropy measure is 0 . This value shows that the samples consist of companies which do not adopt a diversification strategy. Moreover, based on the mean value of three diversification strategies, the value of unrelated diversification is higher than the related diversification. Thus, it means that the level of the unrelated diversification is higher than the level of the related diversification.

Table 3 shows Pearson's correlation matrices for 13 variables. The correlation values between variables are relatively low, except for one case. The correlation between total diversification and unrelated diversification reach 0.82 . In line with correlation matrices result, the Varian inflation factor (VIF) value shows that there is no serious multicollinearity between independent variables and control variables.

\subsection{Regression analysis}

Two regression models (model 2 and model 3) in Table 4 have tested three hypotheses of this study. The model 2 tests the hypothesis 1 and the model 3 examines the hypothesis 2 , and 3. From the model 2 in Table 3, the result shows that the level of diversification is not significantly related to CSP (unstandardized $\beta=-0.046, p=0.627$ ). Therefore, hypothesis 1 is rejected, there is no positive relationship between total diversification and CSP. However, when the total diversification is split based on the type of diversification, the related and unrelated diversification, the result is different. Both of the types of diversification strategy are significantly related to CSP, but in a different sign as shown in the model 3. The related diversification has a negative and significant relationship with CSP (unstandardized $\beta=-11.94, \mathrm{p}=0.001$ ) therefore hypothesis 2 is supported. The unrelated diversification on the other hand, shows a positive and statistically significant relationship with CSP (unstandardized $\beta=4.620, p=0.047$ ) which means that hypothesis 3 is also supported.

\section{Discussion and conclusion}

This study has examined three hypotheses which relate to corporate diversification and CSP relationship. First, this study hypothesizes that total diversification has a positive relationship with CSP (H1). This study found that there is no significant relationship between the total corporate diversification and CSP. The finding of this study does not support some previous studies, such as Qian et al. (2010) who found that total diversification in the context of geographical diversification has a significant and positive impact on organizational performance. Even though Qian et al. did not address CSP as an organizational performance measurement, however, it may argue that corporate diversification may also have a positive and significant relationship with CSP. Su and Tsang (2015) assert a negative and significant relationship between total diversification and company performance. The possible explanation about this finding is that when we combine a positive relationship between unrelated diversification and CSP with a negative relationship between related diversification and CSP it will balance or diminish the effect. Hence, we 


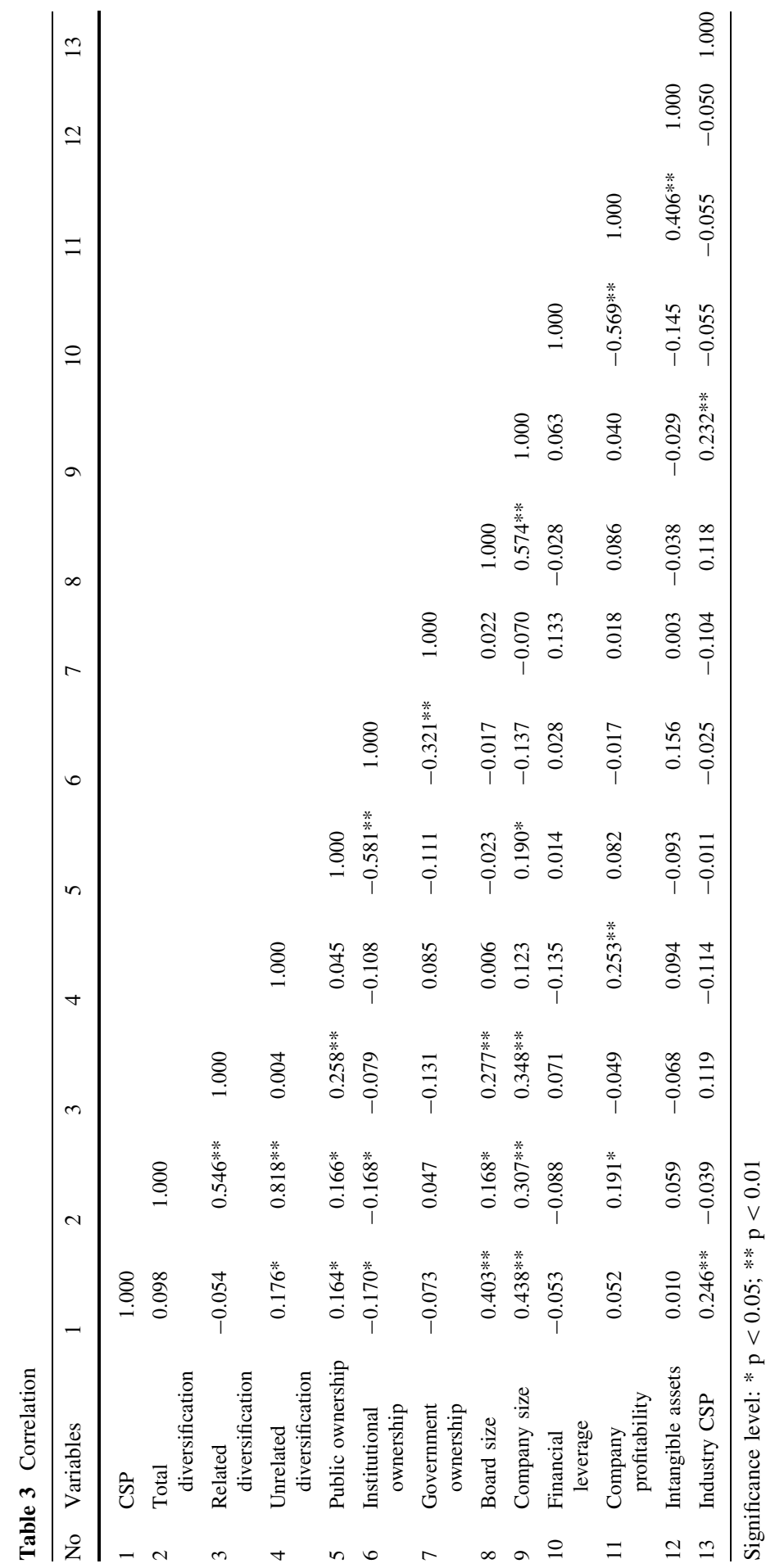




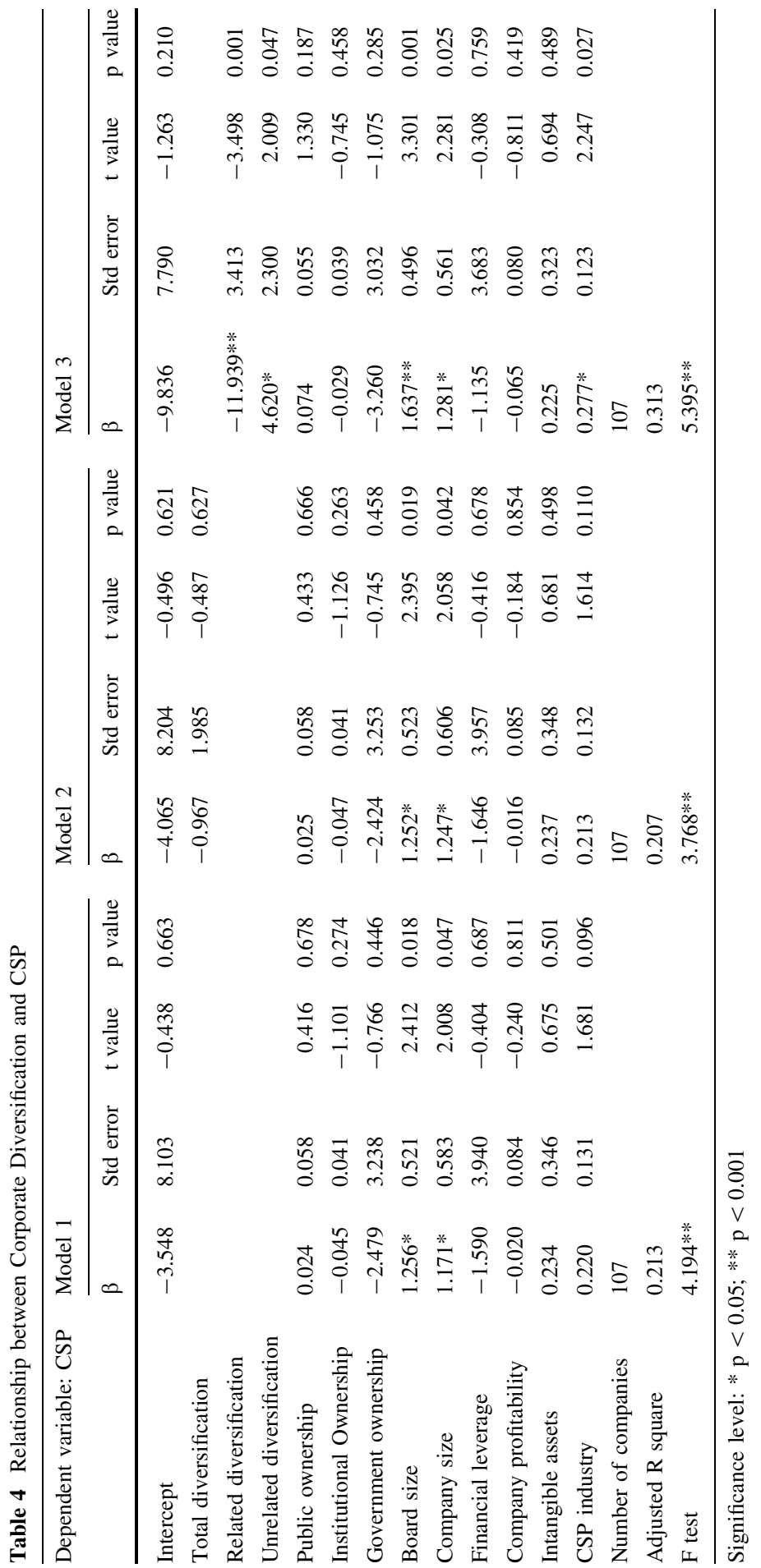


argue that the different direction of these two relationships may become the reason for an insignificant relationship between the level of total diversification and CSP.

However, when the total corporate diversification is divided into two types of diversification; related and unrelated diversification, both of them have a significant relationship with CSP. The related diversification has a negative and significant relationship with CSP (H2). This finding supports some previous studies (Kang 2013; Miller 2006; Su and Tsang 2015). For instance, Su and Tsang (2015) have noted that related diversification has a significant impact on organizational performance. However, Su et al. did not examine CSP as the organizational performance indicator. Moreover, Kang (2013) has found that related diversification has a negative association with CSP but not a significant relationship.

This finding also supports a study from Gary (2005) who noted that related diversification may have a negative impact on a company's performance due to the absence of the management's policies in maintaining organizational slack. Accordingly, we may argue that the negative relationship could happen if a diversified company ignores the rise of stakeholder demands and social issues. Unlike CSR in US and European countries, CSR in Indonesia is primarily promoted by the government rather than the private sector (Park et al. 2015; Waagstein 2011). Although CSR Indonesia Company Law no. 40 of 2007, article 74(1) has stated that social and environmental responsibility is obligatory for a company which has activities in and/or related to natural resources [Indonesia Company Law no. 40 of 2007, article 74(1)], this law does not state specific programmes for the company's CSR. Moreover, institutional environmental pressures will be different in a different industry (Chiu and Sharfman 2011; Jackson and Apostolakou 2010). Therefore, if a related diversified company operates in a non-natural resources industry, it will not be motivated to implement CSR programmes and a related diversified company will not be encouraged to increase its corporate social performance.

Furthermore, we found that the relationship between unrelated diversification and CSP is positively significant (H3). This finding is congruent with some previous studies (Chatterjee and Wernerfelt 1991; Kang 2013; Kim 1989; Palepu 1985; Park 2002; Park and Jang 2013; Su and Tsang 2015). For instance, Kang (2013) notes that there is a significant and positive relationship between unrelated diversification and CSP. Moreover, Kim et al. (1989) assert that unrelated diversification is an antecedent of organizational performance. In addition, Su and Tsang (2015) have asserted that unrelated diversification has a positive and significant relationship with organizational performance. However, both $\mathrm{Kim}$ et al. and $\mathrm{Su}$ et al. have not addressed CSP as the organizational performance yet.

\section{Contribution of study, limitations and future research}

This study has some contributions, including theoretical contributions and managerial implications. This study has provided some theoretical contributions as follows: It gives additional insight about the relationship between corporate diversification and CSP. To the best of the researcher's knowledge, only Kang (2013) has investigated the link between corporate diversification and corporate 
social performance. However, Kang employed KLD as the indicators of corporate social performance instead of other indicators, such as GRI (Bouten et al. 2011; Cuadrado-Ballesteros et al. 2015). Moreover, this study has contributed in calculating the CSP measurement by using content analysis based on the GRI Indicator, which is different to other previous studies (i.e. Jizi et al. 2014; Kang 2013). In addition, this study has been conducted in a developing country which has different characteristics from previous studies which are conducted in developed countries. Furthermore, we also provide some implications for managers and policy makers. This study helps the managers to understand how the diversification strategy affects corporate performance (i.e. CSP). Accordingly, to increase the CSP of the company, a manager should give more attention to unrelated diversification which has a positive and significant impact on CSP. Even though related diversification strategy has a negative impact on CSP, it also has a significant relationship. Hence a manager may also be concerned with related diversification in order to maintain CSP. Finally, for the government as the policy maker and one of the company's stakeholders, this study may become an input to develop a regulation that can increase the company's willingness to share their activities on social responsibility issues.

Furthermore, this study also has some limitations. First, this study has been conducted only in one emerging country (i.e. Indonesia). Indeed, this will affect the generalizability issue. This study only examined the relationship between corporate diversification and CSP in Indonesia. Hence, the researcher cannot justify it as a generalization for all emerging countries. Second, due to time and cost limitations, this study employed a cross-sectional study. Thus, it only portrays the phenomena at a single point in time and it will not be able to reflect the long-term effects of the change. Third, this study only uses manufacturing industries. Accordingly, this study suggests several recommendations for future study. First, this study might be extended to multiple countries, such as South East Asian countries (i.e. Malaysia, Thailand and Philippines). Second, the future study might use the longitudinal study which describes phenomena in the long-term. Hence, the longitudinal study might be able to describe the link between corporate diversification and CSP in a different time and will be able to measure the relationship's consistency or validity. In addition, the longitudinal study may lead practitioners and academicians to understand the causal relationship between corporate diversification and CSP. This study has not captured the corporate diversification based on market or geography, therefore, it is interesting to explore this relationship in the developing countries setting.

Open Access This article is distributed under the terms of the Creative Commons Attribution 4.0 International License (http://creativecommons.org/licenses/by/4.0/), which permits unrestricted use, distribution, and reproduction in any medium, provided you give appropriate credit to the original author(s) and the source, provide a link to the Creative Commons license, and indicate if changes were made.

\section{References}

Aguilera-Caracuel, J., Guerrero-Villegas, J., Vidal-Salazar, M. D., \& Delgado-Márquez, B. L. (2015). International cultural diversification and corporate social performance in multinational enterprises: 
The role of slack financial resources. Management International Review, 55(3), 323-353. doi:10. 1007/s11575-014-0225-4.

Alesón, M. R., \& Escuer, M. E. (2002). The impact of product diversification strategy on the corporate performance of large Spanish companies. Spanish Economic Review, 4(2), 119-137. doi:10.1007/ s101080200042.

Amit, R., \& Livnat, J. (1988a). A concept of conglomerate diversification. Journal of Management, 14(4), 593-604. doi:10.1177/014920638801400409.

Amit, R., \& Livnat, J. (1988b). Diversification strategies, business cycles and economic performance. Strategic Management Journal, 9(2), 99-110. doi:10.1002/smj.4250090202.

Ataullah, A., Davidson, I., Le, H., \& Wood, G. (2014). Corporate diversification, information asymmetry and insider trading. British Journal of Management, 25(2), 228-251. doi:10.1111/j.1467-8551.2012. 00846.x.

Barney, J. B. (2011). Gaining and sustaining competitive advantage. Boston, Mass.: Pearson.

Berger, P. G., \& Ofek, E. (1995). Diversifications effect on company value. Journal of Financial Economics, 37(1), 39-65.

Bouten, L., Everaert, P., Van Liedekerke, L., De Moor, L., \& Christiaens, J. (2011). Corporate social responsibility reporting: A comprehensive picture? Accounting Forum, 35(3), 187-204. doi:10. 1016/j.accfor.2011.06.007.

BPS. (2009). Klasifikasi Baku Lapangan Usaha Indonesia. Jakarta: BPS.

Brammer, S. J., \& Millington, A. (2008). Does it pay to be different? An analysis of the relationship between corporate social and financial performance. Strategic Management Journal, 29(12), 1325-1343.

Brammer, S. J., Pavelin, S., \& Porter, L. A. (2006). Corporate social performance and geographical diversification. Journal of Business Research, 59(9), 1025-1034. doi:10.1016/j.jbusres.2006.04.001.

Castañer, X., \& Kavadis, N. (2013). Does good governance prevent bad strategy? A study of corporate governance, financial diversification, and value creation by French corporations 2000-2006. Strategic Management Journal, 34(7), 863-876.

Chang, S.-C., \& Wang, C.-F. (2007). The effect of product diversification strategies on the relationship between international diversification and company performance. Journal of world business, 42(1), 61-79. doi:10.1016/j.jwb.2006.11.002.

Chatterjee, S., \& Wernerfelt, B. (1991). The link between resources and type of diversification: Theory and evidence. Strategic Management Journal, 12(1), 33-48. doi:10.1002/smj.4250120104.

Chen, C.-J., \& Yu, C.-M. J. (2012). Managerial ownership, diversification, and company performance: evidence from an emerging market. Journal of Management Studies, 21(3), 518-534.

Chiu, S.-C., \& Sharfman, M. (2011). Legitimacy, visibility, and the antecedents of corporate social performance: An investigation of the instrumental perspective. Journal of Management, 37(6), 1558-1585. doi:10.1177/0149206309347958.

Clarkson, M. B. E. (1995). A stakeholder framework for analyzing and evaluating corporate social performance. The Academy of Management Review, 20(1), 92-117.

Cuadrado-Ballesteros, B., Rodríguez-Ariza, L., \& García-Sánchez, I.-M. (2015). The role of independent directors at family companies in relation to corporate social responsibility disclosures. International Business Review, 24(5), 890-901. doi:10.1016/j.ibusrev.2015.04.002.

Dam, L., \& Scholtens, B. (2012). Does ownership type matter for corporate social responsibility? Corporate Governance, 20(3), 233-252. doi:10.1111/j.1467-8683.2011.00907.x.

Dam, L., \& Scholtens, B. (2013). Ownership concentration and CSR policy of european multinational enterprises. Journal of Business Ethics, 118(1), 117-126. doi:10.1007/s10551-012-1574-1.

Doaei, M., Anuar, M. B. A., \& Hamid, N. I. N. A. (2012). Corporate diversification and financial performance: a review of literature. Asian Journal of Finance \& Accounting, 4(2), 56-74.

Erdorf, S., Hartmann-Wendels, T., Heinrichs, N., \& Matz, M. (2013). Corporate diversification and company value: A survey of recent literature. Financial Markets and Portfolio Management, 27(2), 187-215. doi:10.1007/s11408-013-0209-6.

Farneti, F., \& Guthrie, J. (2009). Sustainability reporting by Australian public sector organisations: why they report. Accounting Forum, 33(2), 89-98. doi:10.1016/j.accfor.2009.04.002.

Gamerschlag, R., Möller, K., \& Verbeeten, F. (2011). Determinants of voluntary CSR disclosure: Empirical evidence from Germany. Review of Managerial Science, 5(2), 233-262. doi:10.1007/ s11846-010-0052-3.

Gary, M. S. (2005). Implementation strategy and performance outcomes in related diversification. Strategic Management Journal, 26(7), 643-664. doi:10.1002/smj.468. 
George, R., \& Kabir, R. (2012). Heterogeneity in business groups and the corporate diversificationcompany performance relationship. Journal of Business Research, 65(3), 412-420. doi:10.1016/j. jbusres.2011.07.005.

Hair, J. F., Black, W. C., Babin, B. J., \& Anderson, R. E. (2010). Multivariate data analysis (7th ed.). New Jersey: Prentice Hall.

Harrison, J. S., \& Wicks, A. C. (2013). Stakeholder theory, value, and company performance. Business Ethics Quarterly, 23(1), 97-124.

Hashai, N. (2015). Within-industry diversification and company performance-An S-shaped hypothesis. Strategic Management Journal, 36(9), 1378-1400. doi:10.1002/smj.2290.

Hoskisson, R. E., \& Hitt, M. A. (1988). Strategic control systems and relative R\&D investment in large multiproduct companies. Strategic Management Journal, 9(6), 605-621. doi:10.1002/smj. 4250090607.

Huang, X. B., \& Watson, L. (2015). Corporate social responsibility research in accounting. Journal of Accounting Literature, 34, 1-16. doi:10.1016/j.acclit.2015.03.001.

Jackson, G., \& Apostolakou, A. (2010). Corporate social responsibility in Western Europe: An institutional mirror or substitute? Journal of Business Ethics, 94(3), 371-394. doi:10.1007/s10551009-0269-8.

Jacquemin, A. P., \& Berry, C. H. (1979). Entropy measure of diversification and corporate growth. The Journal of Industrial Economics, 27(4), 359-369.

Jizi, M. I., Salama, A., Dixon, R., \& Stratling, R. (2014). Corporate governance and corporate social responsibility disclosure: Evidence from the US banking sector. Journal of Business Ethics, 125(4), 601-615. doi:10.1007/s10551-013-1929-2.

Joseph, C., \& Taplin, R. (2011). The measurement of sustainability disclosure: Abundance versus occurrence. Accounting Forum, 35(1), 19-31. doi:10.1016/j.accfor.2010.11.002.

Kacperczyk, A. (2009). With greater power comes greater responsibility? Takeover protection and corporate attention to stakeholders. Strategic Management Journal, 30(3), 261-285.

Kang, J. (2013). The relationship between corporate diversification and corporate social performance. Strategic Management Journal, 34(1), 94-109. doi:10.1002/smj.2005.

Kaplan, R. S., \& Norton, D. P. (1996). The balanced scorecard: translating strategy into action. Boston, Mass: Harvard Business School Press.

Khan, A., Muttakin, M. B., \& Siddiqui, J. (2013). Corporate governance and corporate social responsibility disclosures: Evidence from an emerging economy. Journal of Business Ethics, 114(2), 207-223. doi:10.1007/s10551-012-1336-0.

Kilic, M., Kuzey, C., \& Uyar, A. (2015). The impact of ownership and board structure on corporate social responsibility (CSR) reporting in the Turkish banking industry. Corporate Governance, 15(3), 357-374. doi:10.1108/CG-02-2014-0022.

Kim, W. C. (1989). NOTES: Developing a global diversification measure. Management Science, 35(3), 376.

Kim, W. C., Hwang, P., \& Burgers, W. P. (1989). Global diversification strategy and corporate profit performance. Strategic Management Journal, 10(1), 45-57. doi:10.1002/smj.4250100105.

Kim, K.-H., \& Rasheed, A. A. (2014). Board heterogeneity, corporate diversification and company performance. Journal of Management Research, 14(2), 121.

Kranenburg, H., Hagedoorn, J., \& Pennings, J. (2004). Measurement of international and product diversification in the publishing industry. The Journal of Media Economics, 17(2), 87-104. doi:10. 1207/s15327736me1702_2.

Lahouel, B. B., Peretti, J.-M., \& Autissier, D. (2014). Stakeholder power and corporate social performance: The ownership effect. Corporate Governance, 14(3), 363-381. doi:10.1108/CG-072012-0056.

Larry, D. S. (2010). Ownership structure, corporate diversification and capital structure. Management Decision, 48(2), 314-339. doi:10.1108/00251741011022644.

Li, S., Song, X., \& Wu, H. (2015). Political connection, ownership structure, and corporate philanthropy in China: A strategic-political perspective. Journal of Business Ethics, 129(2), 399-411. doi:10. 1007/s10551-014-2167-y.

Lien, Y.-C., \& Li, S. (2013). Does diversification add company value in emerging economies? Effect of corporate governance. Journal of Business Research, 66(12), 2425.

Luo, X., \& Bhattacharya, C. B. (2009). The debate over doing good: Corporate social performance, strategic marketing levers, and company-idiosyncratic risk. Journal of Marketing, 73(6), 198-213. doi:10.1509/jmkg.73.6.198. 
Markides, C. C., \& Williamson, P. J. (1994). Related diversification, core competencies and corporate performance. Strategic Management Journal, 15, 149-165.

Martin, J. D., \& Sayrak, A. (2003). Corporate diversification and shareholder value: A survey of recent literature. Journal of Corporate Finance, 9(1), 37-57. doi:10.1016/s0929-1199(01)00053-0.

McGuire, J., Dow, S., \& Ibrahim, B. (2012). All in the family? Social performance and corporate governance in the family company. Journal of Business Research, 65(11), 1643-1650.

McWilliams, A., \& Siegel, D. (2001). Corporate social responsibility: A theory of the company perspective. The Academy of Management Review, 26(1), 117-127.

Miller, D. J. (2006). Technological diversity, related diversification, and company performance. Strategic Management Journal, 27(7), 601-619. doi:10.1002/smj.533.

Montgomery, C. A. (1994). Corporate diversification. The Journal of Economic Perspectives, 8(3), $163-178$.

Nation, U. (2008). International Standard Industrial Classification of All Economic Activities (ISIC), Rev. 4. New York: United Nation.

Neubaum, D. O., \& Zahra, S. A. (2006). Institutional ownership and corporate social performance: The moderating effects of investment horizon, activism, and coordination. Journal of Management, 32(1), 108-131.

Ntim, C. G., \& Soobaroyen, T. (2013). Corporate governance and performance in socially responsible corporations: New empirical insights from a neo-institutional framework. Corporate Governance: An International Review, 21(5), 468-494. doi:10.1111/corg.12026.

Oh, C. H., Sohl, T., \& Rugman, A. M. (2015). Regional and product diversification and the performance of retail multinationals. Journal of International Management, 21(3), 220-234. doi:10.1016/j. intman.2015.04.002.

Palepu, K. (1985). Diversification strategy, profit performance and the entropy measure. Strategic Management Journal, 6(3), 239-255. doi:10.1002/smj.4250060305.

Palich, L. E., Cardinal, L. B., \& Miller, C. C. (2000). Curvilinearity in the diversification-performance linkage: An examination of over three decades of research. Strategic Management Journal, 21(2), 155-174. doi:10.1002/(SICI)1097-0266(200002)21:2<155:AID-SMJ82>3.0.CO;2-2.

Park, C. (2002). The effects of prior performance on the choice between related and unrelated acquisitions: Implications for the performance consequences of diversification strategy. Journal of Management Studies, 39(7), 1003-1019. doi:10.1111/1467-6486.00321.

Park, K., \& Jang, S. S. (2012). Effect of diversification on company performance: Application of the entropy measure. International Journal of Hospitality Management, 31(1), 218-228. doi:10.1016/j. ijhm.2011.03.011.

Park, K., \& Jang, S. (2013). Capital structure, free cash flow, diversification and company performance: A holistic analysis. International Journal of Hospitality Management, 33(1), 51-63. doi:10.1016/j. ijhm.2013.01.007.

Park, C. W., Milberg, S., \& Lawson, R. (1991). Evaluation of brand extensions: The role of product feature similarity and brand concept consistency. Journal of Consumer Research, 18(2), 185-193. doi:10.1086/209251.

Park, Y.-R., Song, S., Choe, S., \& Baik, Y. (2015). Corporate social responsibility in international business: Illustrations from Korean and Japanese electronics MNEs in Indonesia. Journal of Business Ethics, 129(3), 747-761. doi:10.1007/s10551-014-2212-x.

Peng, C.-W., \& Yang, M.-L. (2014). The effect of corporate social performance on financial performance: The moderating effect of ownership concentration. Journal of Business Ethics, 123(1), 171-182. doi:10.1007/s10551-013-1809-9.

Purkayastha, S. (2013). Diversification strategy and company performance: Evidence from Indian manufacturing companies. Global Business Review, 14(1), 1-23.

Purkayastha, S., Manolova, T. S., \& Edelman, L. F. (2012). Diversification and performance in developed and emerging market contexts: A review of the literature. International Journal of Management Reviews, 14(1), 18-38.

Qian, Z., Qian, G., Khoury, T. A., \& Peng, M. W. (2010). The performance implications of intra-and inter-regional geographic diversification. Strategic Management Journal, 31(9), 1018-1030. doi:10. 1002/smj.855.

Raghunathan, S. P. (1995). A refinement of the entropy measure of company diversification: Toward definitional and computational accuracy. Journal of Management, 21(5), 989-1002. doi:10.1016/ 0149-2063(95)90051-9. 
Rumelt, R. P. (1974). Strategy, structure and economic performance. Cambridge, MA: Harvard University Press.

Sahut, J. M., Hikkerova, L., \& Khalfallah, M. (2013). Business model and performance of companies. International Business Research, 6(2), 64.

Sambharya, R. B. (2000). Assessing the construct validity of strategic and SIC-based measures of corporate diversification. British Journal of Management, 11(2), 163-173. doi:10.1111/1467-8551. t01-1-00158.

Shleifer, A., \& Vinishny, R. W. (1989). Management entrenchment: The case of manager-specific investment. Journal of Financial Economics, 25, 123-139.

Simerly, R. L. (1997). An empirical examination of the relationship between corporate social performance and companies' diversification. Psychological Reports, 80(3), 1347-1356. doi:10. 2466/pr0.1997.80.3c.1347.

Soana, M.-G. (2011). The relationship between corporate social performance and corporate financial performance in the banking sector. Journal of Business Ethics, 104(1), 133-148.

Strike, V. M., Gao, J., \& Bansal, P. (2006). Being good while being bad: Social responsibility and the international diversification of US companies. Journal of International Business Studies, 37(6), 850-862. doi:10.1057/palgrave.jibs.8400226.

Su, W., \& Tsang, E. W. K. (2015). Product diversification and financial performance: The moderating role of secondary stakeholders. Academy of Management Journal, 58(4), 1128-1148. doi:10.5465/ amj.2013.0454.

Waagstein, P. R. (2011). The mandatory corporate social responsibility in Indonesia: Problems and implications. Journal of Business Ethics, 98(3), 455-466. doi:10.1007/s10551-010-0587-x.

Walls, J. L., Berrone, P., \& Phan, P. H. (2012). Corporate governance and environmental performance: Is there really a link? Strategic Management Journal, 33(8), 885-913.

Wood, D. J. (2010). Measuring corporate social performance: a review. International Journal of Management Reviews, 12(1), 50-84.

Zahavi, T., \& Lavie, D. (2013). Intra-industry diversification and company performance. Strategic Management Journal, 34(8), 978-998. doi:10.1002/smj.2057.

Zhang, L. (2012). Board demographic diversity, independence, and corporate social performance. Corporate Governance, 12(5), 686-700. 